\title{
Rupture of megadolicho basilar artery anomaly
}

\author{
Takashi Watari, ${ }^{1}$ Taro Shimizu, ${ }^{2}$ Yasuharu Tokuda ${ }^{3}$
}

${ }^{1}$ Shonan Kamakura General Hospital, Kamakura City, Kanagawa, Japan

${ }^{2}$ Tokyo Joto Hospital, Koutou-ku, Tokyo, Japan ${ }^{3}$ Department of Medicine, Tsukuba University, Mito, Ibaraki, Japan

\section{Correspondence to}

Professor Yasuharu Tokuda, yasuharu.tokuda@gmail.com

Accepted 19 November 2014

\section{DESCRIPTION}

Enlargement and ectasia of the basilar artery as a consequence of fusiform aneurysm is described as megadolicho basilar artery (MBA) anomaly. MBA can cause ischaemic events of the posterior circulation or compression of the adjacent nerves; or, rarely, subarachnoid haemorrhage (SAH). Non-invasive diagnostic tests for delineating MBA include three-dimensional CT angiography and MR angiography. ${ }^{1} 2$

We report a case of a 70-year-old woman who presented with sudden onset of dysarthria and mild left hemiparesis. Head CT scan showed a markedly tortuous and dilated basilar artery without haemorrhage (figure 1A).

Diffusion-weighted MRI at this point revealed a high-intensity area at right pons, indicating a small area of infarction (figure $1 \mathrm{~B}$ ). MR angiography revealed a basilar artery extending $20 \mathrm{~mm}$ beyond the dorsum sellae, where a saccular and fusiform aneurysm was observed (figure 1C).

Three hours after arrival in hospital, and during insertion of a nasogastric tube, the patient became comatose. An additional plain head CT scan revealed massive SAH, especially in the basal, prepontine and insular cisterns (figure 2). The imaging appearance of SAH suggested that it was caused by the rupture of the MBA. The patient's condition deteriorated rapidly and she died a few hours later.

\section{Learning points}

- MR angiography can show megadolicho basilar artery (MBA) anomaly.

- MBA anomaly can lead to impairment of the cranial nerves, cerebral ischaemia and haemorrhage.

- Placement of a nasogastric tube in patients with MBA anomaly may trigger its rupture.

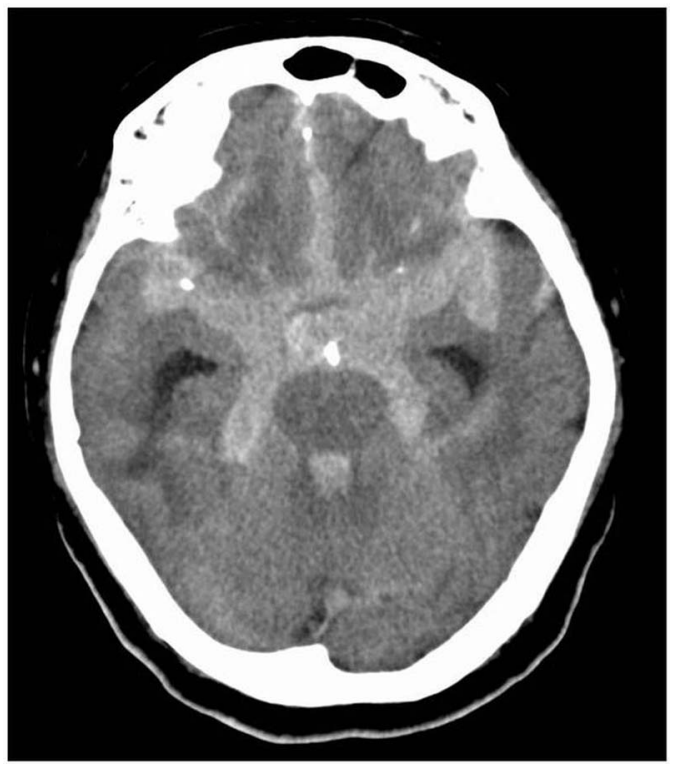

Figure 2 Head CT scan showing massive subarachnoid haemorrhage.

Contributors TW cared for the patient, and TW, TS and YT wrote the paper.

\section{Competing interests None.}

Patient consent Obtained.

Provenance and peer review Not commissioned; externally pee reviewed.

\section{REFERENCES}

1 Yoshida M, Asano M. Direct compression by megadolichobasilar anomaly as a cause of trigeminal neuralgia; a case diagnosed by MRI. Tohoku J Exp Med 1994;172:327-32.

2 Resta M, Genitile MA, Di Cuonzo F, et al. Clinical-angiographic correlations in 132 patients with megadolichovertebrobasilar anomaly. Neurodariology 1984;26:213-16.
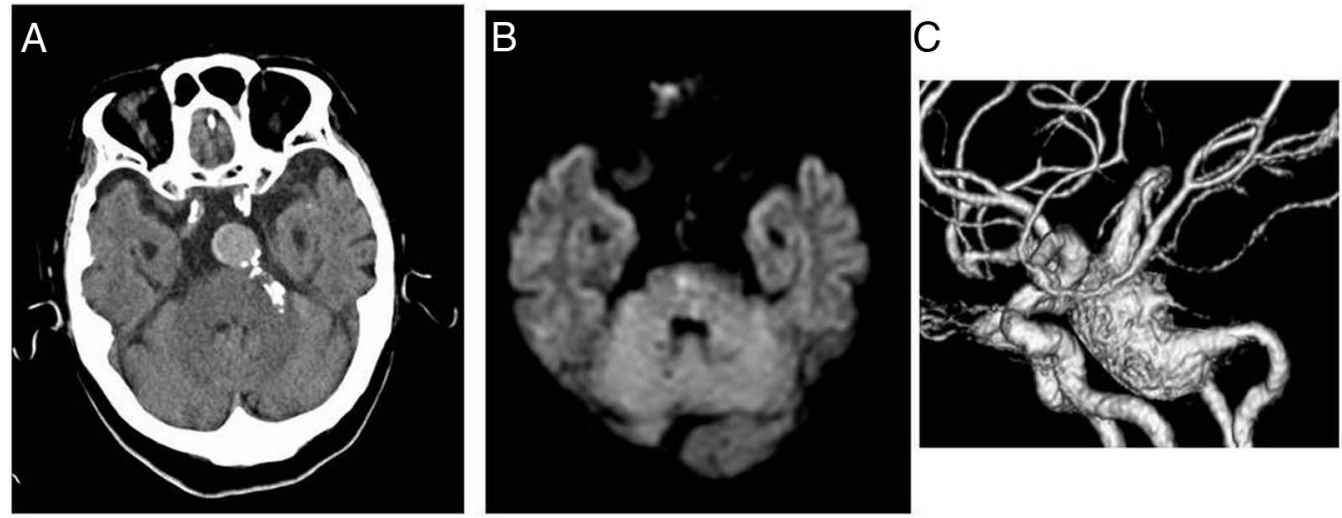

Figure 1 (A) Non-contrast head CT scan showing markedly dilated and tortuous basilar artery. (B) Diffusionweighted MRI revealing high-intensity lesion at right pons. (C) Reconstruction three-dimensional image of MR angiography showing megadolicho basilar artery anomaly. 
Copyright 2014 BMJ Publishing Group. All rights reserved. For permission to reuse any of this content visit http://group.bmj.com/group/rights-licensing/permissions.

BMJ Case Report Fellows may re-use this article for personal use and teaching without any further permission.

Become a Fellow of BMJ Case Reports today and you can:

- Submit as many cases as you like

- Enjoy fast sympathetic peer review and rapid publication of accepted articles

- Access all the published articles

- Re-use any of the published material for personal use and teaching without further permission

For information on Institutional Fellowships contact consortiasales@bmjgroup.com

Visit casereports.bmj.com for more articles like this and to become a Fellow 